\title{
The representativeness of the dental calculus dietary record: insights from Taï chimpanzee faecal phytoliths
}

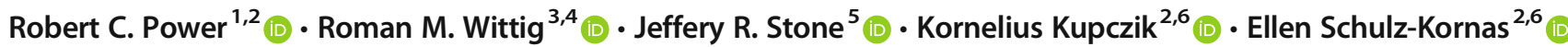

Received: 29 December 2019 / Accepted: 12 April 2021 / Published online: 29 May 2021

(C) The Author(s) 2021

\begin{abstract}
In recent years, new applications of microremain dietary analysis using dental calculus as a source of dietary data on ancient human subsistence and behaviours have accelerated. The dental calculus of contemporary human and non-human populations with known diets have been used as reference datasets, including the chimpanzees of Taï National Park (Côte d'Ivoire), but explaining the preservation mechanism involved is challenged by our incomplete knowledge of the microremain content within the diets of these reference populations and our rudimentary information on microremain incorporation into dental calculus. Here, we analyse phytoliths in faecal samples to assess to what extent plant phytoliths of a diet are reflected in the dental calculus as well as in the egested faeces. In this study, we identify and document the faecal phytolith assemblages as an indicator of plant consumption in two Western chimpanzees of the Taï National Park (Côte d'Ivoire) before (wet season), during (dry season) and after (dry season) a dust-rich period. Moreover, observational dietary records of these two individuals were compiled to improve the interpretability of this dental calculus phytolith dataset. The faecal phytolith assemblages vary significantly across samples in terms of abundance and diversity. The most common phytolith morphotypes were eudicot plates, single-cell and multi-cell tracheids, monocot rugulose and echinate spheroids and, to a lesser extent, unspecified thick and thin elongates. High loads of grit and other micro-remains (e.g. diatoms) are found during the dry period. Using observational dietary records as a starting point and our faecal results as a terminus, we consider how dental calculus can accumulate phytoliths. Our findings enable identification of the phytolith morphotypes that are under-represented in dental calculus, which is highly informative for future dental calculus research strategies.
\end{abstract}

Keywords Plants $\cdot$ Micro-remains $\cdot$ Rainforest $\cdot$ Ivory Coast $\cdot$ Taphonomy $\cdot$ Plant consumption

Robert C. Power

robert_power@eva.mpg.de

1 Institute for Pre-and Protohistoric Archaeology and Archaeology of the Roman Provinces, Ludwig-Maximilians-University Munich, Munich, Germany

2 Department of Human Evolution, Max Planck Institute for Evolutionary Anthropology, Leipzig, Germany

3 Department of Primatology, Max Planck Institute of Evolutionary Anthropology, Leipzig, Germany

4 Taï Chimpanzee Project, Centre Suisse de Recherches Scientifiques, Abidjan, Côte d'Ivoire

5 Department of Earth and Environmental Systems, Indiana State University, Terre Haute, IN, USA

6 Max Planck Weizmann Center for Integrative Archaeology and Anthropology, Max Planck Institute of Evolutionary Anthropology, Leipzig, Germany

\section{Introduction}

In recent years, human dental calculus has received increased interest as a source of life history information. Researchers have sought to answer outstanding questions on the development and change of human subsistence using micro-remains and other dietary remains. An increasing amount of literature has examined phytolith applications in archaeological dental calculus (Deng et al. 2018; Dunseth et al. 2019; Wroth et al. 2019) and palaeoecological research (Chabot, Garnier, and Geria 2018; Crifò and Strömberg 2020; Delhon et al. 2003; Novello et al. 2018); however, researchers still largely do not understand the formation processes of dental calculus dietary records or even dental calculus itself (Radini et al. 2017). Given that only a small number of phytoliths and starches are present, and that molecular evidence of diet is generally sparse in dental calculus, it is accepted that dental calculus fails to provide a detailed picture of diet and is, at best, a 
generalised picture. However, there are competing theories, and some argue that dental calculus mostly produces a random unreliable picture (Weyrich, Dobney, and Cooper 2015), while others believe it can provide valuable dietary insights (Leonard et al. 2015; Power et al. 2015). As the use of starch and phytoliths in dental calculus has accelerated, researchers have attempted to measure the reliability of starches and phytoliths in recording plant consumption and broader dietary patterns. Researchers have examined dental calculus from populations with well-documented diets, including living human forager-horticulturists from Namibia and skeletal wild chimpanzees from Côte d'Ivoire, with local reference plant collections to measure the ability of calculus to reflect diet in these two environments (Leonard et al. 2015; Power et al. 2015). These studies have set a benchmark on dental calculus' dietary micro-remains coverage, but they also highlight discrepancies that exist between diet and dental calculus microremain assemblages. Some discrepancies are expected due to the high number of plant taxa that produce few or no diagnostic starches and phytoliths (Torrence and Barton 2006; Tsartsidou et al. 2007). Further variation is anticipated due to local evapotranspiration-driven differences in phytolith production (Jenkins, Jamjoum, and Nuimat 2011). However, researchers have identified a disparity even when plants that do not make phytoliths and plants that make few phytoliths (low producers) are accounted for (Tsartsidou et al. 2007). Specific micro-remains from staple and non-staple foods have been found to be overrepresented, such as the starch grains of maize (a Twe staple) and the phytoliths of oil palm (a minor chimpanzee food) (Leonard et al. 2015; Power et al. 2015).

In some archaeological contexts, phytolith assemblages are mostly composed of digested phytoliths (Albert et al. 2008). Though phytoliths that pass through the gastrointestinal tract have been studied for their potential for reconstructing human behaviour (Gur-Arieh et al. 2014; Phillips and Lancelotti 2014; Shahack-Gross 2011), few studies have examined the impact of this process on the assemblages. It is not clear how mammalian digestion affects phytoliths, despite the fact that phytoliths are frequently encountered damaged, and we need to understand the damage patterns that often affect them (Madella and Lancelotti 2012). The inconsistency between dietary records and dental calculus data in chimpanzees and humans indicates unexplained biases exist in dental calculus assemblages of starch grains and phytoliths (Leonard et al. 2015; Power et al. 2015). These undermine the validity of dietary interpretations of calculus data. These problems cannot be resolved simply by using reference plants of possible diets alone. One factor in this discrepancy that is characteristic of Taï chimpanzees is that they frequently absorb plant nutrients by chewing plant material into wadage without swallowing the food bolus. Presumably, this causes a reduction in exposure to phytoliths. Additionally, most chimpanzee feeding records do not specify the plant part consumed or give weights of consumed foods. Lastly, local factors can influence phytolith content in plants. Phytolith content can vary seasonally in response to moisture availability and evapotranspiration, meaning that no reference collection can replicate true chimpanzee phytolith exposure (Jenkins et al. 2011; Rosen and Weiner 1994).

Also, other micro-remains can be found in dental calculus, including the microscopic skeletons of algae and sponges (diatoms and sponge spicules), both of which are linked to aquatic environments. They have been interpreted as potentially offering an alternative method to reconstruct the use of water (Dudgeon and Tromp 2014). How these micro-remains enter dental calculus is understood poorly, because experimental studies are lacking.

To rectify these problems, we examined phytolith assemblages from faeces of Western chimpanzees of the Taï National Park (Côte d'Ivoire) (Schulz-Kornas et al. 2019) to document the phytolith types that are missing from the published chimpanzee dental calculus (Power et al. 2015) and possibly systematically underrepresented across dietary studies. This will generate the first complete model of a mammalian interface with the phytoliths in their natural environment. Chimpanzees of the Taï National Park have a highly diverse diet composed of hundreds of plant and other species and are an ideal model for the dietary reconstruction of historic human and fossil hominin populations (Boesch and BoeschAchermann 2000).

Annually, Taï chimpanzees are exposed to high levels of airborne dust, which accumulates on plants eaten by these animals during dry periods. Between December and February, this Aeolian dust is transported by north-easterly surface winds (Harmattan) blowing from the Sahara Desert over West Africa into the Gulf of Guinea (Engelstaedter and Washington 2007; Stoorvogel, Van Breemen, and Jassen 1997). The dust-laden Harmattan reaches the Taï National Park for a few weeks, depositing $60-100 \mathrm{~kg} / \mathrm{ha}$ of uniformly graded materials in the canopy of the Tail forest ecosystem (Elipe and Lopez-Querol 2014; Stoorvogel et al. 1997; Wittig 2018). The dust particles have a size distribution of fine sand $(50-125 \mu \mathrm{m})$, silt $(2-50 \mu \mathrm{m})$ and clay (below $2 \mu \mathrm{m})$; approximately $69 \%$ of the dust typically is in the silt range (Enete et al. 2011).

Here, we present a unique case study where phytolith representation and feeding data of a well-known chimpanzee population are available (Boesch and Boesch-Achermann 2000; Falchi et al. 2014; Power et al. 2015). We aim to determine and quantify the phytolith, diatom and mineral particle abundance and morphotypes in the faecal samples and compare these results to published dental calculus phytolith data of the same chimpanzee population (Power et al. 2015). Additionally, we consider the effects of digestion on phytoliths. This allows us to use the faecal phytolith record to establish the usefulness of dental calculus assemblages. 


\section{Methods}

Fourteen faecal samples were collected from two habituated male chimpanzees, the individuals Poseidon (Pos) and Athos (Ath), living in the East Group of the chimpanzee population of the Taï National Park in southwest Côte d'Ivoire (Wittig and Boesch 2019). This chimpanzee population has detailed behavioural and dietary records from 1992 until the present. The faecal samples were collected from the two target chimpanzees as part of the study on feeding ecology and chewing efficiency at intervals between December 2014 and March 2015 (Schulz-Kornas et al. 2019). Each sample was weighed, preserved in $96 \%$ ethanol and later freeze-dried following the procedure for faecal particle size analysis as described in Schulz-Kornas et al. (2019).

These samples were collected in the field over 19 weeks, from December to March, primarily as part of a faecal particle size analysis study. We made use of 11 dry-sieved size fractions, each of which were analysed and weighed in the labs of the Max Planck Weizmann Center for Integrative Archaeology and Anthropology, Max Planck Institute of Evolutionary Anthropology (Leipzig, Germany). We selected the three smallest fractions $(20,40$ and $63 \mu \mathrm{m})$ for phytolith analysis following Power, Rosen and Nadel (2014). These sizes were selected because they represent the size range of phytoliths recovered from dental calculus. We then processed each of the three samples by dry-ashing in a muffle oven at $500{ }^{\circ} \mathrm{C}$ for $4 \mathrm{~h}$ in the labs of the Department of Human Evolution, Max Planck Institute for Evolutionary Anthropology (Leipzig, Germany). After cooling, calcites were removed from each sample by gradually adding $10 \%$ $\mathrm{HCl}$ for $10 \mathrm{~min}$ in $1.5-\mathrm{ml}$ centrifuge tubes. A weighed subsample of the residue was mounted in Entellan New (Merck) with a $24 \times 24-\mathrm{mm}$ or $22 \times 22$-mm coverslip, depending on mounted mass.

Phytoliths and all other encountered micro-remains were counted at $\times 400$ magnification (Num. Aperture $=0.95$ ) using a field of view counting method with a light microscope (Axio scope A1, Zeiss). We counted single cells until we documented 250 or more examples (in some cases up to 500 cells) per sample, including unidentified phytoliths (Supplementary Table 1). We classified phytoliths into as many categories as were deemed useful to the project (Supplementary Table 2).

Samples for scanning electron microscope analyses were mounted on carbon tape or dried onto aluminium specimen stubs and then mounted to stubs with carbon tape. All samples were sputter-coated with gold on a Denton Desk V sputter coater for $1.5 \mathrm{~min}$ at $50 \mathrm{amps}$. Images were collected by a secondary detector at $10 \mathrm{kV}$ with working distances ranging from 21 to $5 \mathrm{~mm}$ on a TESCAN Vega 3 Scanning Electron Microscope.

Multi-cellular phytoliths were counted both as multi-celled entities and as single cells by individually recording each cell.
For single-celled monocot phytoliths, we followed the ICPN classification system when possible ((ICPT) 2019; Madella, Alexandre, and Ball 2005). The number of phytoliths on the slide was calculated using the following algorithm:

$n$ phytoliths per slide $=n$ counted $/$ fields counted

$$
\times \text { total fields on slide }
$$

This value was used to derive a comparable unit of quantification-the number of phytoliths per gram of sediment. This value was calculated with the following formula:

$n$ phytoliths/gram

$$
\begin{aligned}
= & n \text { phytoliths per slide/total amount of sediment mounted }(\mathrm{mg}) \\
& \times \text { total phytolith amount }(\mathrm{mg}) / \text { total initial sediment }(\mathrm{mg}) \\
& \times 1000
\end{aligned}
$$

The three values from each sample were combined, and the resulting information was compared with existing information on phytoliths in Taï Chimpanzee dental calculus (Power et al. 2015, 2014).

Observational dietary records taken by researchers standing no less than $7 \mathrm{~m}$ from a subject were obtained from the East Group Chimpanzees for comparison (Supplementary Fig. 1). Observational data were not available for Pos and Ath from all of the dates, so we sourced data from the relevant dates from across the East Group population from October 2007 to August 2017 to generate a reliable overview. The total observation time was approximately 10,000 hours of feeding data from $27,000 \mathrm{~h}$ of behavioural data. The data includes observation of 41 chimpanzees (16 males and 21 females). Taï chimpanzees primarily consume ripe eudicot fruit, although leaves, piths, nuts from eudicots, monocots and magnoliids are also used (Supplementary Figs. 1, 2, 3). We choose to sample 10 years of data because it averages out yearly fluctuations in fruiting phenology, which commonly occurs in the Taï Forest. We analysed feeding data based on its taxonomic families, genera and plant part, rather than based on the properties of each food (hard versus tough foods) or based on being chewed wadage or swallowed foods because this information is not available. Taxonomic information and the plant parts consumed were specifically marked in 104,000 entries of the record set.

Although surveys have been conducted of Western and Central African phytoliths, particularly savannahs, surveys of forests are incomplete, and they lack detailed coverage of the 'Upper Guinea' rainforest habitats that comprise the Taï Forest (Barboni and Bremond 2009; Collura 2017; Runge 1999). Additionally detailed phytolith classification that exceeded Power et al. (2015) in specificity was unnecessary. Because of this, we took a minimalist approach to 
identification, and we classified phytoliths principally into the 15 groupings used in Power et al. (2015), which was based on a reference collection of 113 species. To support this information, we also prepared 52 phytolith samples of 45 unstudied plant species of Taï food plants using nitric acid-based wet ashing to assess their morphotypes (Supplementary Table 3) (Piperno 2006).

\section{Results}

\section{Phytolith abundance}

The phytolith concentration (measured as the number of phytoliths/g of dried faeces within the 20-63 $\mu \mathrm{m}$ fraction) varies significantly across different samples (Fig. 1). While some samples had only hundreds/g or no phytoliths, others contained high numbers $(47,000 / \mathrm{g})$ with a mean of $18,906 /$ g. Generally, samples with a higher per cent of acidinsoluble fractions also had a higher number of phytoliths, but in many cases, this pattern was not present (Fig. 1; Table 1). In most samples, the acid-insoluble fraction varied from 0.9 to $5.6 \%$. However, in two samples, it far exceeds this, reaching over 19\%. These samples did not exhibit a corresponding increase in the number of phytoliths. As a whole, across the samples, there was no relationship evident between the acid-insoluble fraction and the number of multi-celled phytoliths (Table 1).

\section{Phytolith morphotype representation}

The number of phytoliths that can be readily identified closely followed the total number of phytoliths/g (Supplementary
Table 1; Table 2). The most common types were monocot rugulose phytoliths and echinate spheroids (21\% of all phytoliths), unspecific thick and thin elongates (14\%) and eudicot plates, single-cell and multi-cell tracheids (11\%) (Table 3; Fig. 2). Rarer types that were present include grass short-cells, which were less than $1 \%$ including reniforms, widelobe narrow-shank bilobates, flat bilobates, square trapezoid, ovals, rondels, and saddles. We also found occasional grass bulliforms, hairs, psilate and sinuate long-cell as well as eudicot multi-cellular honeycomb polygons, jigsaws, sclereids and thick decorated elongates, blocks and more ambiguous psilate thick oblongs and some other types (Supplementary Table 2). Cylindroid, hair bases and eudicot-type hairs were rare (below $2 \%$ ). We did not find cystoliths.

\section{Diatoms and sponge spicules}

Diatoms occurred in low levels and in most samples were rare ( $<2 \%$ of all micro-remains) (Table 3$)$. Diatoms were not systematically identified but observed species present in samples included the following genera: Orthoseira, Rhopalodia, Gomphonema, Caloneis and Nitzschia (Supplementary Fig. 4). Orthoseira are chainforming aerophytic taxa that are typically found on wet surfaces, mosses and tree-bark (Spaulding and Kociolek 1998). The other diatom genera observed are all representative of shallow aquatic or semi-aquatic systems, typically found living attached to macrophytes, rocky or muddy substrates (Wehr, Sheath and Kociolek 2015). Diatoms were most abundant in the sample of Pos from the 10th of Dec. Sponge spicules were considerably rarer than diatoms $(<0.2 \%$ of all micro-remains $)$ and were absent from most samples.

Table 1 Summary of analysed samples and phytolith extraction information

\begin{tabular}{|c|c|c|c|c|c|c|c|c|}
\hline ID & Birth year & Sampling date & Weight (mg) of residue & $\%$ acid insoluble & N. phytoliths/g & Multi-cell \% & Fresh matter $(\mathrm{g})$ & $\%$ 20-63 $\mu \mathrm{m}$ sieves \\
\hline ATH & 1994 & 08 Dec 2014 & 3.807 & 2.76 & 212 & 2.67 & 15 & 4.7 \\
\hline ATH & 1994 & 24 Dec 2014 & 61.106 & 18.03 & 34,235 & 2.3 & 15 & 1.1 \\
\hline ATH & 1994 & 06 Jan 2015 & 51.99 & 19.84 & 13,191 & 0.8 & 15 & 6.4 \\
\hline ATH & 1994 & 06 Jan 2015 & 4.580 & 4.31 & 29,638 & 2.13 & 15 & 13.9 \\
\hline ATH & 1994 & 19 Jan 2015 & 0.719 & 0.43 & 5,206 & 0 & 15 & 2.3 \\
\hline ATH & 1994 & 05 Feb 2015 & 7.116 & 3.79 & 7,911 & 2.41 & 15 & 11.2 \\
\hline ATH & 1994 & 02 Mar 2015 & 5.886 & 1.21 & 47,820 & 4.7 & 15 & 7.8 \\
\hline ATH & 1994 & 16 Mar 2015 & 3.500 & 0.97 & 0 & 5.27 & 15 & 2.2 \\
\hline POS & 1998 & 10 Dec 2014 & 4.121 & 3.6 & 640 & 0.89 & 20 & 5.7 \\
\hline POS & 1998 & 23 Dec 2014 & 10.177 & 2.62 & 24,604 & 1.12 & 17 & 11.3 \\
\hline POS & 1998 & 06 Jan 2015 & 9.529 & 5.78 & 19,638 & 4.29 & 21 & 32.1 \\
\hline POS & 1998 & 02 Jan 2015 & 8.429 & 4.11 & 33,495 & 4.69 & 19 & 22.7 \\
\hline POS & 1998 & 02 Mar 2015 & 5.886 & 5.38 & 3,005 & 2.58 & 19.1 & 24.1 \\
\hline POS & 1998 & 16 Mar 2015 & 16.374 & 3.89 & 20,392 & 7.11 & 19 & 27.5 \\
\hline
\end{tabular}


Fig. 1 a Total number of phytoliths in each in faecal sample with date of origin. b Per cent insoluble fraction in each in faecal sample, with the date of the Harmattan indicated in shading. High values in late December and January indicate that airborne dust becomes abundant in diet during the Harmattan.

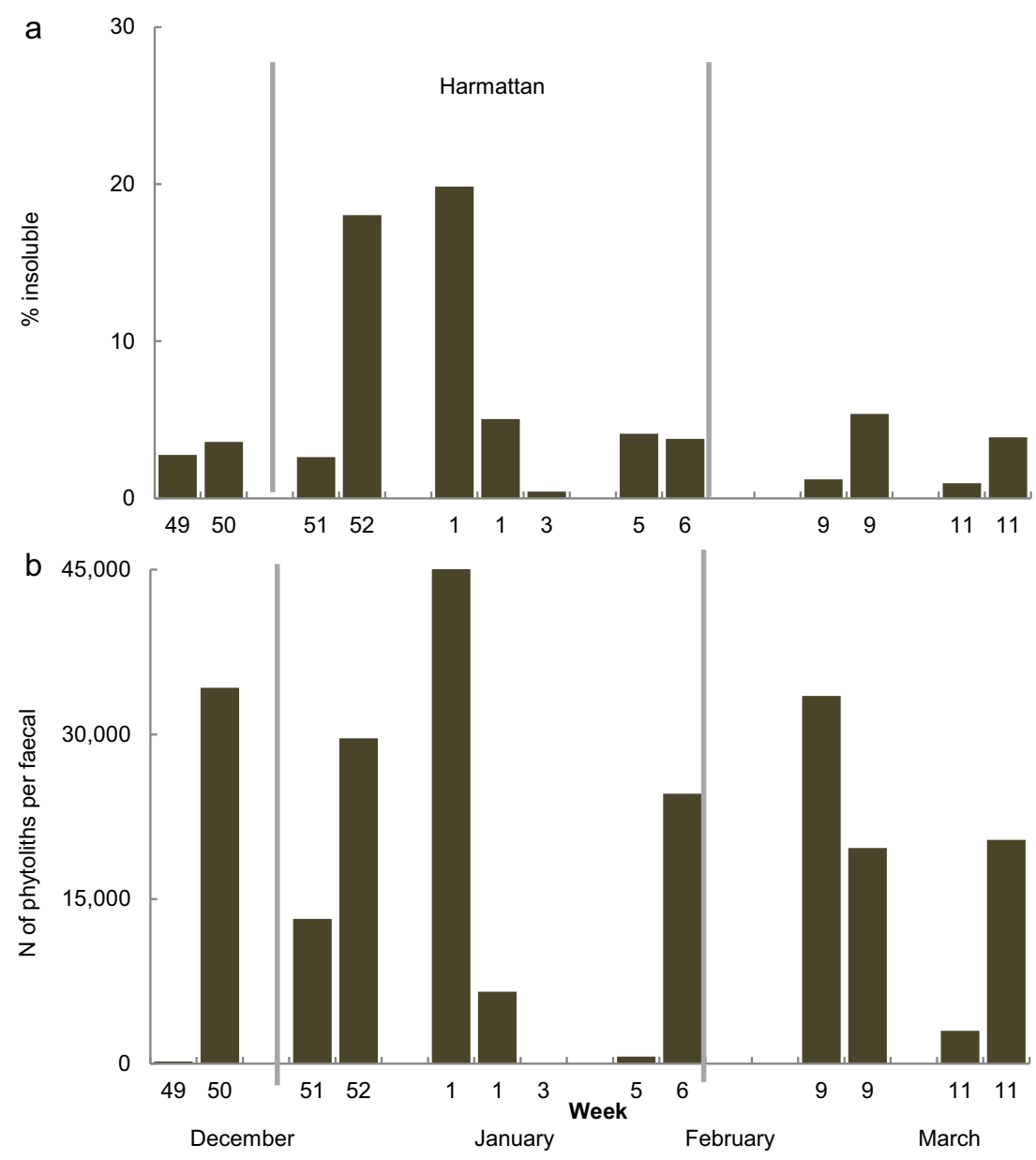

\section{Geological inclusions (grit content)}

Very large angular $(5-3000 \mu \mathrm{m}$, but mostly $40-200 \mu \mathrm{m})$ birefringent mineral particles from dust were common in many samples (Supplementary Fig. 5). Some examples exhibited considerable wear. In Ath 24 Dec 2014 and Ath 6 Jan 2015, these particles were extremely common, greatly outnumbering phytoliths on the slides and in some cases made counting phytoliths challenging. The acid-insoluble fraction of the faecal samples showed that on occasion, these grit particles were extremely common and far more abundant than phytoliths. Peaks in grit content were apparent around the period associated with the Harmattan (Fig. $1)$.

\section{Discussion}

\section{Representativeness of morphotypes}

The phytolith morphotypes of the faecal samples of the Taï chimpanzees are largely comparable to published Kibale chimpanzee faecal phytolith datasets (Phillips and Lancelotti
2014). The abundance of eudicot plate, tracheid phytoliths is similar to Kibale chimpanzees (Phillips and Lancelotti 2014), reflecting the eudicot-rich forest world and eudicot-based diet of both chimpanzee groups. The principal differences relate to the relative abundance of monocot rugulose and echinate spheroids in the Taï (Côte d'Ivoire) samples versus the Kanyawara, Kibale National Park (Uganda). We assume that this reflects underlying dietary differences between the two on a geographic and on a taxonomic level, i.e. subspecies of Pan troglodytes and distinct localities. The decorated rugulose/ globular/spheroid phytoliths are produced by Zingiberaceae, which are commonly consumed at both localities. However, sub-variants are also produced by Marantaceae and especially Arecaceae, which are families that are consumed by chimpanzees in the Taï forest but not Kibale (Phillips and Lancelotti 2014; Power et al. 2015; Watts et al. 2012). There are other differences, too; the phytoliths consumed by the chimpanzees in Kibale appear to show more stomata, hair-base and hair morphotypes, although the reason for this is not clear. In addition, morphotypes were generally ubiquitous amongst Tai samples compared to those from Uganda, although this may relate to the shorter sampling window at Taï, 100 days from December to March, compared to 162 days over June to 
Table 2 Summary of taxa represented by phytoliths (n/dry gram).

\begin{tabular}{lllllllll}
\hline Sample: & Eudicots & Palms & Grasses & Gingers & Woods & Sedges & Diatoms & Spicule \\
\hline ATH_8_Dec & 28 & 0 & 17 & 0 & 0 & 0 & 0 & 6 \\
ATH_24_Dec & 6,355 & 6,031 & 1,074 & 536 & 182 & 0 & 232 & 0 \\
ATH_6_Jan & 2,159 & 3,323 & 860 & 62 & 356 & 0 & 143 & 0 \\
ATH_6_Jan & 4,092 & 10,934 & 535 & 393 & 157 & 0 & 33 & 0 \\
ATH_19_Jan & 612 & 667 & 22 & 0 & 159 & 0 & 0 & 0 \\
ATH_5_Feb & 2,375 & 339 & 278 & 802 & 0 & 0 & 198 & 0 \\
ATH_2_Mar & 13,300 & 8,687 & 1,288 & 1,385 & 1,910 & 0 & 5 & 0 \\
ATH_16_Mar & 0 & 0 & 0 & 0 & 0 & 0 & 41 & 0 \\
POS_10_Dec & 220 & 0 & 40 & 70 & 0 & 0 & 1918 & 0 \\
POS_23_Dec & 11,675 & 66 & 462 & 792 & 0 & 146 & 126 & 0 \\
POS_6_Jan & 3,451 & 891 & 187 & 292 & 25 & 0 & 170 & 0 \\
POS_2_Feb & 12,502 & 1,563 & 584 & 0 & 0 & 0 & 50 & 0 \\
POS_2_Mar & 699 & 396 & 150 & 0 & 60 & 0 & 0 & 0 \\
POS_16_Mar & 8,640 & 1,183 & 708 & 0 & 156 & 149 & 78 & 0 \\
\hline
\end{tabular}

December at Kibale. Contrasting these two signals is challenging because of our incomplete botanical knowledge of these two environments. Although surveys have been conducted of phytolith assemblages of Western and Central Africa, particularly of the savannahs, surveys of forests are incomplete and lack detailed coverage of the 'Upper Guinea' rainforests that comprise the habits of the Taï Forest (Collura 2017; Runge 1999).

\section{Representativeness of inferred diet}

The phytolith record has varying levels of representation. Although eudicots are known to produce few phytoliths, they are well represented in all samples, particularly by tracheids types (Table 3 ). The types of eudicot foods that are rare in chimpanzee diet are also rare in the samples, such as wood and sedge. Grasses occur in the samples, although grasses are not consumed at Taï, nor do they do use grass as tools (Whiten et al. 1999), and grass is not abundant in their habitat. The presence of grasses plausibly could be linked to accidental inhalation of wind-blown grass phytoliths, or via accumulated dust adhering to foods. This explanation is plausible given that grasses produce very high numbers of phytoliths. Palms (monocots) are overrepresented but this is unsurprising given the high production in palm and other monocot plants, which are important chimpanzee staples (Supplementary Figs. 1 and 2). Marantaceae is an important food including the staple Halopegia pith; however, we were not able to identify any phytoliths from this family (Fig. 3). Overall, the faecal phytoliths more strongly reflect the Taï diet over the represented period than the dental calculus record (Table 3). However, it also represents their annual diet much better than dental calculus.

\section{Phytolith and dental calculus records}

The faecal samples present rich assemblages, even though chimpanzees engage in dietary behaviours that reduce the consumption of phytoliths. For example, chimpanzees consume a high amount of tree and shrub fruit and leaves (Boesch and Boesch-Achermann 2000). Taï forest fruit and leaves are thick and leathery, and chimpanzees chew them into wadage, for example, fig fruit (Boesch and BoeschAchermann 2000), to absorb leaf nutrients without swallowing the fibrous and phytolith-rich wadage. The composition of the faecal phytolith assemblages is diverse, even though only two individuals were represented over a few months. Samples with abundant phytoliths also produced the most diverse assemblages. This reflects the diverse Taï diet, which includes at least 48 plant genera according to feeding observations (Schulz-Kornas et al. 2019) and at least 43 families during the seasonal window represented by the faecal samples of the present study (Supplementary Table 4). Although we do not have personalised feeding records from the immediate period prior to faecal sampling, analysis of the feeding data shows that several species may be consumed in 1 day (Supplementary Fig. 3). Although dental calculus represents years of life (Silverstone et al. 1981), the dental calculus assemblages were not as diverse as expected (compare Figs. 1 and 3). Therefore, we suggest that this indicates that dental calculus phytoliths omit a great deal of dietary diversity. In faecal samples, palms and gingers were moderately overrepresented. However, this overrepresentation contrasts with the dental calculus assemblages, which had substantial overrepresentation of these types. In contrast, the morphotypes, such as parallelepipedal and tracheids, seem to be disproportionately rare in the dental calculus even though they occur in greater abundance in their diet. 
Table 3 Comparing consumed plant taxa and taxa inferred from faecal phytolith assemblage and dental calculus. As identified foods and as phytolith morphotypes, with time spent consuming in feeding data; excludes unidentified phytoliths

\begin{tabular}{|c|c|c|c|c|c|c|}
\hline \multirow[t]{3}{*}{ Identified foods } & \multirow{2}{*}{\multicolumn{2}{|c|}{ Count }} & & & \multicolumn{2}{|c|}{ Time consumed in feeding data } \\
\hline & & & \multicolumn{2}{|c|}{ Percentage of plant diet } & \multirow[t]{2}{*}{ Count $(\mathrm{h} / \mathrm{min} / \mathbf{s})$} & \multirow[t]{2}{*}{ Percentage of plant diet } \\
\hline & Calculus & Faecal & Calculus & Faecal & & \\
\hline Palms and gingers & 1369 & 41510 & 92 & 34 & 21:01:00 & 0.63 \\
\hline Eudicots & 70 & 66109 & 5 & 54 & $3296: 26: 00$ & 99 \\
\hline Grasses & 28 & 6205 & 2 & 5 & & \\
\hline Woods & 0 & 3005 & 0.00 & 2.45 & 01:07:00 & 0.03 \\
\hline Diatoms & 16 & 3593 & 1 & 3 & 11:20:00 & $0.33^{\mathrm{a}}$ \\
\hline Sedges & 0 & 700 & 0.00 & 0.57 & 01:20:00 & \\
\hline Feathers & 8 & 700 & 0.54 & 0.57 & Unavailable & $0.3^{\mathrm{b}}$ \\
\hline Spicules & 0 & 700 & 0.00 & 0.57 & & \\
\hline \multicolumn{7}{|l|}{ Morphotypes } \\
\hline & \multicolumn{2}{|l|}{ Count } & \multicolumn{2}{|c|}{ Percentage of diet } & & \\
\hline & Calculus & Faecal & Calculus & Faecal & & \\
\hline Unidentified phytoliths & 89 & 66772 & 4.88 & 37.43 & & \\
\hline Spheroid echinates & 1369 & 37459 & 75.10 & 21.00 & & \\
\hline Parallelepipedals & 57 & 25914 & 3.13 & 14.53 & & \\
\hline Tracheids & 4 & 10663 & 0.22 & 5.98 & & \\
\hline Plates & 13 & 10253 & 0.71 & 5.75 & & \\
\hline Long-cells & 106 & 9322 & 5.81 & 5.23 & & \\
\hline Short-cells & 28 & 6205 & 1.54 & 3.48 & & \\
\hline Hair cells & 65 & 3876 & 3.57 & 2.17 & & \\
\hline Bulliforms & 53 & 3503 & 2.91 & 1.96 & & \\
\hline Smooth spheroids/ovals & 0 & 3005 & 0.00 & 1.68 & & \\
\hline Acicular hair cells & 12 & 897 & 0.66 & 0.50 & & \\
\hline Ellipsoids & 7 & 507 & 0.38 & 0.28 & & \\
\hline Cylindroids & 20 & 3 & 1.10 & 0.00 & & \\
\hline
\end{tabular}

${ }^{\mathrm{a}}$ Based on water consumption

${ }^{\mathrm{b}}$ Based on Boesch and Boesch-Acherman (2000)

The reasons for this may relate to the toughness of palm and ginger phytolith types. Palm rugulate and spherical echinate morphotypes are known to resist decay, due to chemical or mechanical properties. This may relate to their bulkiness; they have a large volume to surface area ratios (Cabanes and Shahack-Gross 2015). In addition, their high abundance in dental calculus may relate to the fact that these echinate spheroids possess spines that may more securely embed to form dental plaque. In contrast, many phytolith types are smooth (e.g. parallelepipedals) and may be less likely to attach to dental plaque. In addition, overrepresentation may relate to the phytoliths of palms and gingers being less firmly in their parent plant cells than other phytolith types. Nevertheless, these findings highlight that researchers need to employ caution when using these morphotypes to study palms and gingers. This is important because palms are of key importance in African dietary history and agricultural expansions, as well as for ecological reconstruction (Neumann et al. 2012). Although palms are a key crop of agricultural expansions of Bantu peoples, researchers need to allow for the fact that palm is overrepresented (Maley and Chep 2001; Neumann et al. 2012). When only using phytoliths, the role of tropical eudicots can be overlooked easily; these phytoliths are substantially underrepresented in dental calculus and to a lesser extent in faecal samples.

\section{Effect of digestion}

Of the many processes that can affect phytoliths, digestion by plant-eating species is an important example and may affect the archaeological and palaeoecological phytolith record. Mastication and digestion expose phytoliths to harsh mechanical and chemical processes in the gastrointestinal tract. This has resulted in reports of fractured phytoliths and possibly deform phytoliths (Baker, Jones, and Wardrop 1959; Power and Berthaume 2016; Walker, Hoeck, and Perez 1978). As we only have generalised information on the frequencies of different phytolith morphotypes in each plant food, we cannot 
Fig. 2 Mosaic selection of recovered phytoliths. a Large spheroid echinate from a palm, probably oil palm fruit (Pos 2 March 2015). b Large prolate echinate from a palm (Pos 23 Dec 2014). c Short-celled rondel from a grass (Pos 6 Jan 2015). d Dentate thick block (Pos 2 Feb 2015). e Decorated-margin elongate (Ath 6 Jan 2015). $\mathbf{f}$ Multi-cellular polyhedral honeycomb from a eudicot leaf (Pos 10 Dec 2014). g Hair base from a eudicot leaf (Pos 10 Dec 2014). h Multi-cellular tracheid, from a eudicot leaf (Pos 2 Feb 2015). i Surface decorated elongate from a eudicot (Pos 23 Dec 2014). The black scale bar is $10 \mu \mathrm{m}$
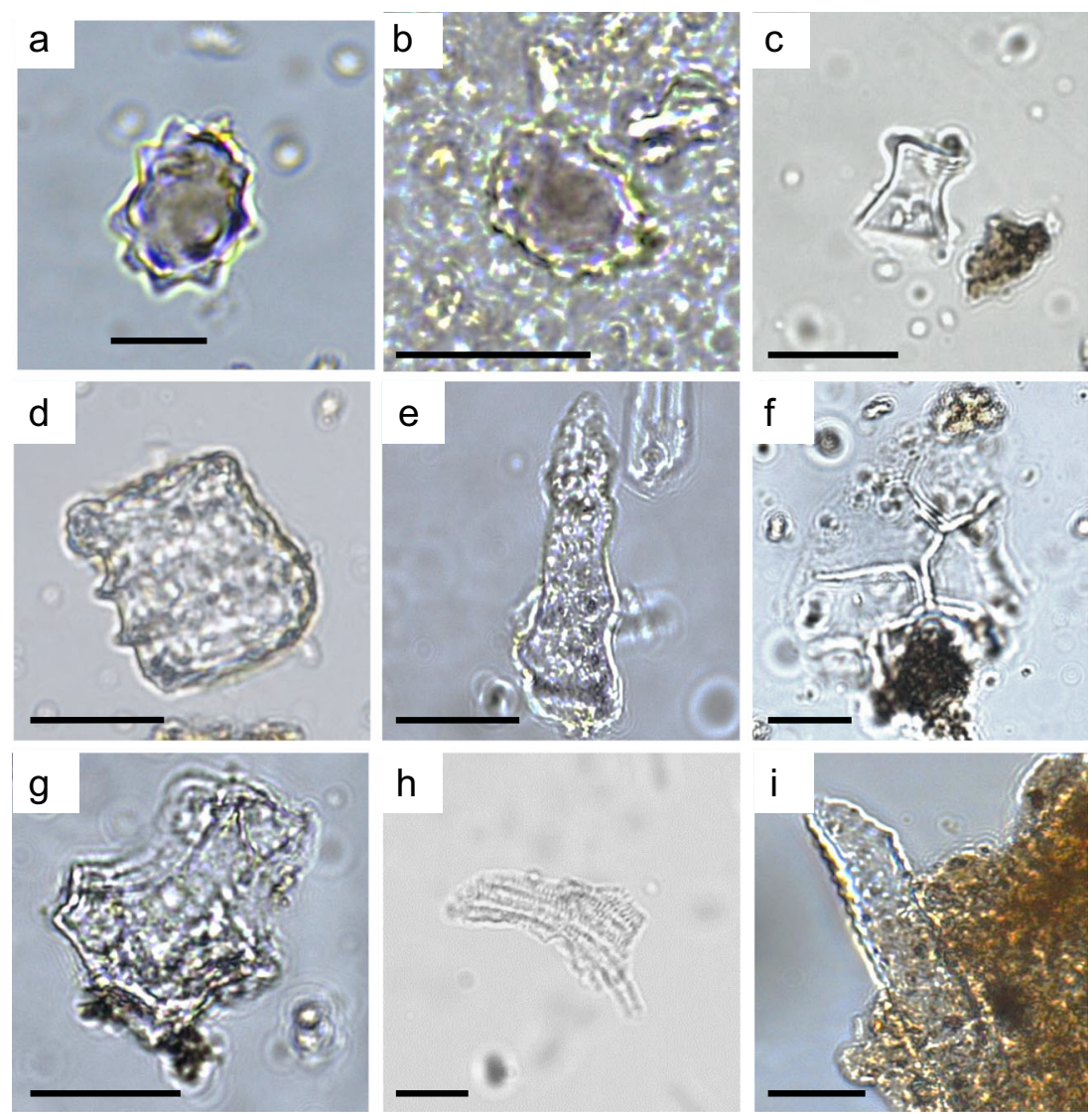

precisely determine if digestion breaks down or dissolves some morphotypes. However, we do note the assemblages underrepresent some phytolith types, such as plates. Other types, such as stoma, hair bases, polygons, irregular and thick types also appear underrepresented. It is not clear if the existing Taï faecal phytoliths are eroded or fractured by digestion, because the morphotypes that occur in the samples are types that do not readily exhibit damage. Although phytoliths such as grass long-cells easily show damage, it is less clear on tracheids and spheroids. However, multi-cellular phytolith forms were less common than expected. For example, multicelled polyhedral forms were infrequent, which is inconsistent with their eudicot-rich diet. This may reflect fracturing of fragile multi-cellular types. Morphotype representation is greater in samples with more phytoliths per gram, possibly suggesting poor preservation (Madella and Lancelotti 2012).

\section{Dietary dust richness}

Phytoliths are a major component of plant resistance to herbivory, and phytolith production is increased by aboveground herbivory (Hartley and DeGabriel 2016; Hodson et al. 2005; Power et al. 2016). Because phytoliths are hard and gritty, they serve as an anti-feedant that actively discourages herbivory by inhibiting nutrient absorption (Moore and Johnson 2017; Sanson, Kerr, and Gross 2007). It has been argued that phytoliths may cause dental wear, which is a ubiquitous feature of ageing teeth (Piperno 1988). Although it is debated if phytolith material properties and ultrastructural morphology are sufficient to drive dental wear (for review (Kaiser et al. 2018; Schulz-Kornas et al. 2017)), hard grit, probably composed of quartz, was common in the faecal samples during the dry season (Harmattan). These particles were often large, often far greater in size $(5-200 \mu \mathrm{m})$ than phytoliths and appeared to be Saharan Aeolian dust. Grass short-cells were also found, which we believe were transported to Taï by the Harmattan, helping to verify Aeolian dust as the likely source. Given that, these indicate a variety of environments, likely including savannahs (Supplementary Fig. 6). In contrast to phytoliths, these particles undoubtedly wear down dental enamel (van Casteren et al. 2018; Kaiser et al. 2015; Lucas et al. 2014). The phytolith content of Taï plant foods vary, but in nearly all foods, it is below $5 \%$ of the dry matter (Supplementary Table 3). Only in seed cases of the Palisota genus have we identified a very high acid-insoluble fraction. However, this plant is a minor food, and Palisota seed cases are reported to be spat out by chimpanzees, so the high phytolith content in this plant cannot explain the high acid-insoluble fraction (e.g. in Ath 24 Dec 2014 and Ath 6 Jan 2015). Nevertheless, it shows that phytoliths are found in seedcases, and eudicotyledoneous seeds have been suggested to be the main reason for tooth 


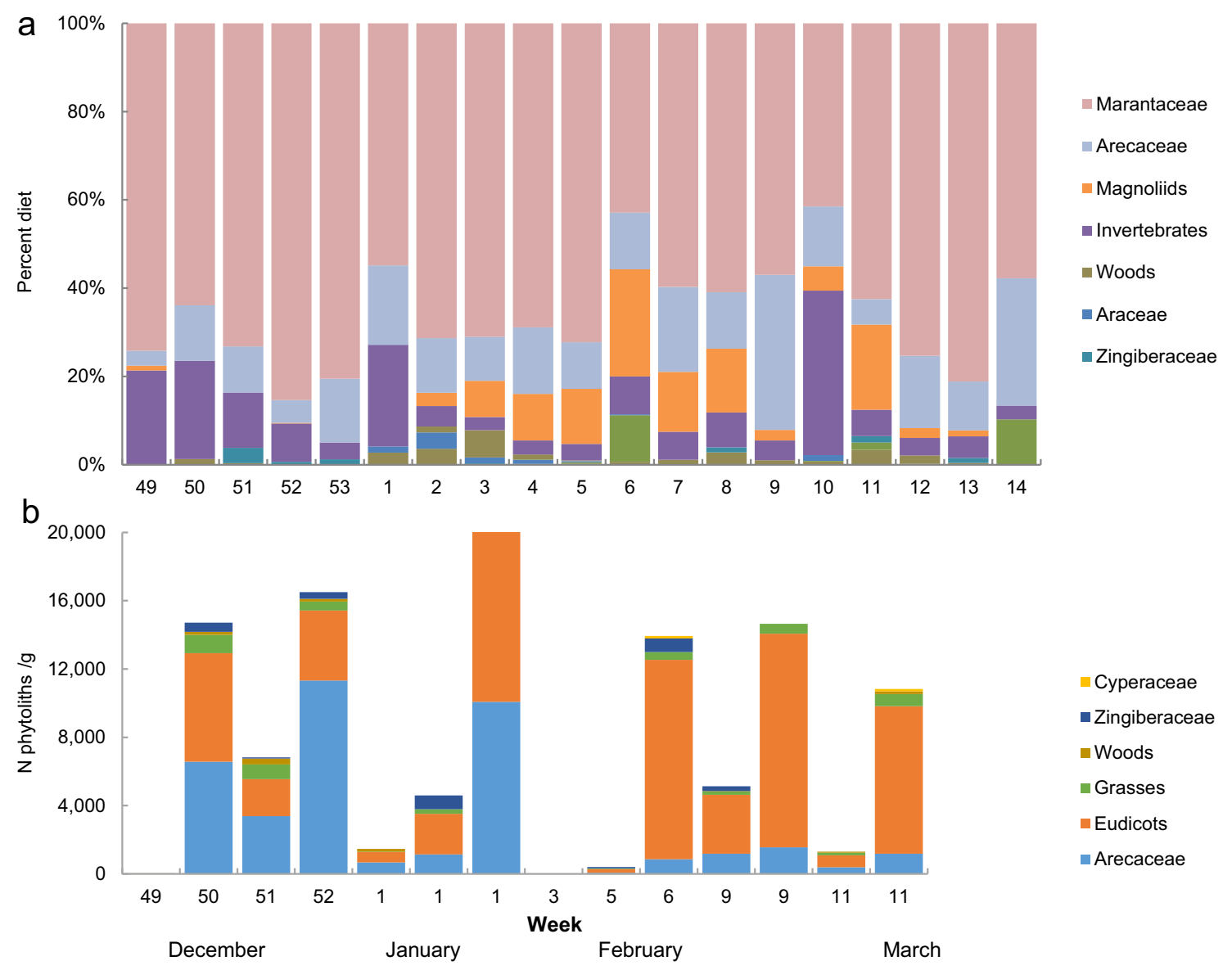

Fig. 3 a Graph of the total diet that produces known diagnostic phytoliths by week. b Graph of diagnostic phytoliths in each faecal sample. Some weeks were represented by several samples from different days, resulting in multiple entries in some weeks in this graph

wear creating large pits (Ragni, Teaford, and Ungar 2017; Ungar and Peter 2008) and valleys (Schulz-Kornas et al. 2019) on primate tooth facets.

\section{Conclusions}

Bringing faecal and dental calculus datasets together addresses some of the methodological concerns researchers have raised about inferring diet from dental calculus. Although this study highlights biases that exist with using dental calculus and faecal samples for reconstructing diet, it also helps to validate that these studies in these regions have produced a signal that is dietary in origin. This study provides important data, crucial for interpreting diet in the African tropics, but further studies with a similar research design are needed to assess the representativeness of dental calculus in other environments and amongst other species.

Supplementary Information The online version contains supplementary material available at https://doi.org/10.1007/s12520-021-01342-z.
Acknowledgements We thank the Ministère de l'Enseignement Supérieur et de la Recherche Scientifique, the Ministère de l'Environnement et des Eaux et Forêts of Côte d'Ivoire and the Office Ivorien des Parcs et Reserves for permission to conduct this research. We are grateful for the support by the Centre Suisse de Recherches Scientifiques at Abidjan, Côte d'Ivoire. We would like to express our gratitude to Amanda G. Henry, Jean-Jacques Hublin, Róisín Murtagh and Tobias Deschner for the access to the research facilities. We thank the field assistants at Taï National Park for the collection of faecal samples. We are thankful to Liran Samuni for helping provide Taï data files and Nicholas Ting for help with programming. We thank Mallory Wilson for assistance with preparation of samples for SEM analyses at Indiana State University. Tina Kottek and Ramona Beuth (Max Planck Weizmann Center for Integrative Archaeology and Anthropology) are thanked for assisting with sieving the faeces.

Funding Open Access funding enabled and organized by Projekt DEAL. Core funding for the Taï Chimpanzee Project is provided by the Max Planck Society since 1997. This research was supported by the Max Planck Society.

Open Access This article is licensed under a Creative Commons Attribution 4.0 International License, which permits use, sharing, adaptation, distribution and reproduction in any medium or format, as long as you give appropriate credit to the original author(s) and the source, provide a link to the Creative Commons licence, and indicate if changes were 
made. The images or other third party material in this article are included in the article's Creative Commons licence, unless indicated otherwise in a credit line to the material. If material is not included in the article's Creative Commons licence and your intended use is not permitted by statutory regulation or exceeds the permitted use, you will need to obtain permission directly from the copyright holder. To view a copy of this licence, visit http://creativecommons.org/licenses/by/4.0/.

\section{References}

(ICPT), International Committee for Phytolith Taxonomy (2019) International Code for Phytolith Nomenclature 2.0 (ICPN 2.0). Ann Bot 124(2):i-iii

Albert RM, Shahack-Gross R, Cabanes D, Gilboa A, Lev-Yadun S, Portillo M, Sharon I, Boaretto E, Weiner S (2008) Phytolith-rich layers from the Late Bronze and Iron Ages at Tel Dor (Israel): mode of formation and archaeological significance. J Archaeol Sci 35(1):57-75

Baker G, Jones LHP, Wardrop ID (1959) Cause of wear in sheeps' teeth. Nature 184(4698):1583-1584

Barboni D, Bremond L (2009) Phytoliths of East African Grasses: an assessment of their environmental and taxonomic significance based on floristic data. Rev Palaeobot Palynol 158(1-2):29-41

Boesch C, Boesch-Achermann H (2000) The Chimpanzees of the Taï Forest: Behavioural Ecology and Evolution. Oxford University Press, Oxford

Cabanes D, Shahack-Gross R (2015) Understanding fossil phytolith preservation: the role of partial dissolution in paleoecology and archaeology. PLoS One 10(5):e0125532

van Casteren A, Oelze VM, Angedakin S, Kalan AK, Kambi M, Boesch C, Kühl HS, Langergraber KE, Piel AK, Stewart FA, Kupczik K (2018) Food mechanical properties and isotopic signatures in forest versus savannah dwelling eastern chimpanzees. Commun Biol 1(1):109

Chabot Y, Garnier A, Made Geria I (2018) Phytolith analysis from the archaeological site of Kota Cina (North Sumatra, Indonesia). J Archaeol Sci Rep 20:483-501

Collura LV (2017) Wood and bark phytoliths of West African woody plants. Quat Int 434:142-159

Crifò C, Strömberg CAE (2020) Small-scale spatial resolution of the soil phytolith record in a rainforest and a dry forest in Costa Rica: applications to the deep-time fossil phytolith record. Palaeogeogr Palaeoclimatol Palaeoecol 537:109107

Delhon C, Alexandre A, Berger J-F, Thiébault S, Brochier J-L, Meunier J-D (2003) Phytolith assemblages as a promising tool for reconstructing Mediterranean holocene vegetation. Quat Res 59(1):48-60

Deng Z, Hung H-c, Fan X, Huang Y, Houyuan L (2018) The Ancient dispersal of millets in Southern China: new archaeological evidence. The Holocene 28(1):34-43

Dudgeon JV, Tromp M (2014) Diet, geography and drinking water in Polynesia: microfossil research from archaeological human dental calculus, Rapa Nui (Easter Island). Int J Osteoarchaeol 24(5): 634-648

Dunseth ZC, Fuks D, Langgut D, Weiss E, Melamed Y, Butler DH, Yan X, Boaretto E, Tepper Y, Bar-Oz G, Shahack-Gross R (2019) Archaeobotanical proxies and archaeological interpretation: a comparative study of phytoliths, pollen and seeds in dung pellets and refuse deposits at Early Islamic Shivta, Negev, Israel. Quat Sci Rev 211:166-185

Elipe MGM, Lopez-Querol S (2014) Aeolian sands: characterization, options of improvement and possible employment in constructionthe state-of-the-art. Constr Build Mater 73(30):728-739
Enete IC, Obienusi EA, Igu IN, Ayadiulo R (2011) Harmattan dust: composition, characteristics and effects on soil fertility in Enugu, Nigeria. Curr J Appl Sci Technol 2(1):72-81

Engelstaedter S, Washington R (2007) Atmospheric controls on the annual cycle of North African dust. J Geophys Res 112(D3):D03103

Falchi M, Moustafa JSE-S, Takousis P, Pesce F, Bonnefond A, Andersson-Assarsson JC, Sudmant PH, Dorajoo R, Al-Shafai MN, Bottolo L, Ozdemir E, So H-C, Davies RW, Patrice A, Dent R, Mangino M, Hysi PG, Dechaume A, Huyvaert M, Skinner J, Pigeyre M, Caiazzo R, Raverdy V, Vaillant E, Field S, Balkau B, Marre M, Visvikis-Siest S, Weill J, Poulain-Godefroy O, Jacobson P, Sjostrom L, Hammond CJ, Deloukas P, Sham PC, McPherson R, Lee J, Shyong Tai E, Sladek R, Lena M. S. Carlsson, Andrew Walley, Evan E. Eichler, Francois Pattou, Timothy D. Spector, and Philippe Froguel. (2014) Low copy number of the salivary amylase gene predisposes to obesity. Nat Genet 46(5):492-497

Gur-Arieh S, Shahack-Gross R, Maeir AM, Lehmann G, Hitchcock LA, Boaretto E (2014) The Taphonomy and preservation of wood and dung ashes found in archaeological cooking installations: case studies from Iron Age Israel. J Archaeol Sci 46:50-67

Hartley SE, DeGabriel JL (2016) The ecology of herbivore-induced silicon defences in grasses edited by. J Cooke Funct Ecol 30(8): $1311-1322$

Hodson MJ, White PJ, Mead A, Broadley MR (2005) Phylogenetic variation in the silicon composition of plants. Ann Bot 96(6): $1027-1046$

Jenkins E, Jamjoum K, Al Nuimat S (2011) Irrigation and phytolith formation: an experimental study. In: Mithen S, Black E (eds) Water, Life and Civilisation: Climate, Environment and Society in the Jordan Valley. Cambridge University Press, Cambridge, pp 347-372

Kaiser TM, Braune C, Kalinka G, Schulz-Kornas E (2018) Nanoindentation of native phytoliths and dental tissues: implications for herbivore-plant combat and dental wear proxies. Evol Syst 2(1):55-63

Kaiser TM, Clauss M, Schulz-Kornas E (2015) A set of hypotheses on tribology of mammalian herbivore teeth. Surf Topogr: Metrol Prop 4(1):014003

Leonard CA, Vashro L, O’Connell JF, Henry AG (2015) Plant microremains in dental calculus as a record of plant consumption: a test with two forager-horticulturalists. J Archaeol Sci Rep 2:449-457

Lucas PW, van Casteren A, Al-Fadhalah K, Almusallam AS, Henry AG, Michael S, Watzke J, Reed DA, Diekwisch TGH, Strait DS, Atkins AG (2014) The role of dust, git and phytoliths in tooth wear. Ann Zool Fenn 51(1-2):143-152

Madella M, Alexandre A, Ball T (2005) International Code for Phytolith Nomenclature 1.0. Ann Bot 96(2):253-260

Madella M, Lancelotti C (2012) Taphonomy and phytoliths: a user manual. Quat Int 275:76-83

Maley J, Chep A (2001) Elaeis Guineensis Jacq. (oil palm) fluctuations in Central Africa during the Late Holocene: climate or human driving forces for this pioneering species? Veg Hist Archaeobotany 10(2): $117-120$

Moore BD, Johnson SN (2017) Get tough, get toxic, or get a bodyguard: identifying candidate traits conferring belowground resistance to herbivores in grasses. Front Plant Sci 7:1925

Neumann K, Bostoen K, Höhn A, Kahlheber S, Ngomanda A, Tchiengué B (2012) First farmers in the Central African rainforest: a view from Southern Cameroon. Quat Int 249:53-62

Novello A, Bamford MK, van Wijk Y, Wurz S (2018) Phytoliths in modern plants and soils from Klasies River, Cape Region (South Africa). Quat Int 464:440-459

Phillips C, Lancelotti C (2014) Chimpanzee diet: phytolithic analysis of feces. Am J Primatol 76(8):757-773 
Piperno DR (1988) Phytolith analysis : an archaeological and geological perspective. Academic Press, San Digeo

Piperno DR (2006) Phytoliths: a comprehensive guide for archaeologists and paleoecologists. AltaMira, Lanham

Power RC, Berthaume MA (2016) Mastication derived changes to phytoliths. International Meeting for Phytolith Research. in International Meeting for Phytolith Research,Aix-en-Provence, France, 14th September

Power RC, Rosen AM, Nadel D (2014) The economic and ritual utilization of plants at the Raqefet Cave Natufian Site: The Evidence from Phytoliths. J Anthropol Archaeol 33(1):49-65

Power RC, Salazar-García DC, Wittig RM, Henry AG (2014) Assessing use and suitability of scanning electron microscopy in the analysis of micro remains in dental calculus. J Archaeol Sci 49:160-169

Power RC, Salazar-García DC, Wittig RM, Freiberg M, Henry AG (2015) Dental calculus evidence of Taï Forest chimpanzee plant consumption and life history transitions. Sci Rep 5:15161

Power SA, Barnett KL, Ochoa-Hueso R, Facey SL, Gibson-Forty EVJ, Hartley SE, Nielsen UN, Tissue DT, Johnson SN (2016) DRI-Grass: a new experimental platform for addressing grassland ecosystem responses to future precipitation scenarios in South-East Australia. Front Plant Sci 7:1373

Radini A, Nikita E, Buckley S, Copeland L, Hardy K (2017) Beyond food: the multiple pathways for inclusion of materials into ancient dental calculus. Am J Phys Anthropol 162:71-83

Ragni AJ, Teaford MF, Ungar PS (2017) A molar microwear texture analysis of Pitheciid Primates. Am J Primatol 79(12):e22697

Rosen AM, Weiner S (1994) Identifying ancient irrigation: a new method using opaline phytoliths from emmer wheat. J Archaeol Sci 21(1): $125-132$

Runge F (1999) The Opal Phytolith Inventory of Soils in Central Africa - quantities, shapes, classification, and spectrA. Rev Palaeobot Palynol 107(1-2):23-53

Sanson GD, Kerr SA, Gross KA (2007) Do silica phytoliths really wear mammalian teeth? J Archaeol Sci 34(4):526-531

Schulz-Kornas E, Braune C, Winkler DE, Kaiser TM (2017) Does silica concentration and phytolith ultrastructure relate to phytolith hardness? Biosurf Biotribol 3(4):135-143

Schulz-Kornas E, Stuhlträger J, Clauss M, Wittig RM, Kupczik K (2019) Dust affects chewing efficiency and tooth wear in forest dwelling Western Chimpanzees (Pan Troglodytes Verus). Am J Phys Anthropol 169(1):66-77

Shahack-Gross R (2011) Herbivorous livestock dung: formation, Taphonomy, methods for identification, and archaeological significance. J Archaeol Sci 38(2):205-218
Silverstone LM, Johnson NW, Hardie JM, Willaims RAD (1981) Dental Caries Aetiology, Pathology and Prevention. Macmillan, London

Spaulding SA, Kociolek JP (1998) The Diatom Genus Orthoseira: ultrastructure and morphological variation in two species from Madagascar with comments on nomenclature in the Genus. Diatom Res 13(1):133-147

Stoorvogel JJ, Van Breemen N, Jassen BH (1997) The nutrient input by Harmattan dust to a forest ecosystem in Côte d'Ivoire, Africa. Biogeochemistry 37(2):145-157

Torrence R, Barton H (2006) In: Torrence R, Barton H (eds) Ancient Starch Research. Left Coast Press, Walnut Creek

Tsartsidou G, Lev-Yadun S, Albert RM, Miller-Rosen A, Efstratiou N, Weiner S (2007) The phytolith archaeological record: strengths and weaknesses evaluated based on a quantitative modern reference collection from Greece. J Archaeol Sci 34(8):1262-1275

Ungar P, Peter (2008) Strong teeth, strong seeds. Nature 452(7188): 703-704

Walker A, Hoeck HN, Perez L (1978) Microwear of mammalian teeth as an indicator of diet. Science 201(4359):908-910

Watts DP, Potts KB, Lwanga JS, Mitani JC (2012) Diet of chimpanzees (Pan Troglodytes Schweinfurthii) at Ngogo, Kibale National Park, Uganda, 1. Diet Composition and Diversity. Am J Primatol 74(2): 114-129

Wehr JD, Sheath RG, Kociolek JP (2015) Freshwater algae of North America: ecology and classification. 2nd editio. Academic Press, London

Weyrich LS, Dobney K, Cooper A (2015) Ancient DNA analysis of dental calculus. J Hum Evol 79:119-124

Whiten A, Goodall J, McGrew WC, Nishida T, Reynolds V, Sugiyama Y, Tutin CEG, Wrangham RW, Boesch C (1999) Cultures in chimpanzees. Nature 399(6737):682-685

Wittig RM (2018) Taï chimpanzees. In: Encyclopedia of Animal Cognition and Behavior. Cham, Springer

Wittig RM, Boesch C (2019) Observation protocol and long-term data collection. In: Boesch C, Wittig RM (eds) The chimpanzees of the Taï forest: 40 years of research. Cambridge University Press, Cambridge

Wroth K, Cabanes D, Marston JM, Aldeias V, Sandgathe D, Turq A, Goldberg P, Dibble HL (2019) Neanderthal plant use and pyrotechnology: phytolith analysis from Roc de Marsal, France. Archaeol Anthropol Sci 11(8):4325-4346

Publisher's note Springer Nature remains neutral with regard to jurisdictional claims in published maps and institutional affiliations. 